\title{
Front Matter: Volume 7910
}

, "Front Matter: Volume 7910," Proc. SPIE 7910, Reporters, Markers, Dyes, Nanoparticles, and Molecular Probes for Biomedical Applications III, 791001 (5 April 2011); doi: 10.1117/12.888802

SPIE. Event: SPIE BiOS, 2011, San Francisco, California, United States 


\section{Reporters, Markers, Dyes, Nanoparticles, and Molecular Probes for Biomedical Applications III}

Samuel Achilefu

Ramesh Raghavachari

Editors

24-26 January 2011

San Francisco, California, United States

Sponsored and Published by

SPIE 
The papers included in this volume were part of the technical conference cited on the cover and title page. Papers were selected and subject to review by the editors and conference program committee. Some conference presentations may not be available for publication. The papers published in these proceedings reflect the work and thoughts of the authors and are published herein as submitted. The publisher is not responsible for the validity of the information or for any outcomes resulting from reliance thereon.

Please use the following format to cite material from this book:

Author(s), "Title of Paper," in Reporters, Markers, Dyes, Nanoparticles, and Molecular Probes for Biomedical Applications III, edited by Samuel Achilefu, Ramesh Raghavachari, Proceedings of SPIE Vol. 7910 (SPIE, Bellingham, WA, 2011) Article CID Number.

ISSN 1605-7422

ISBN 9780819484475

Published by

SPIE

P.O. Box 10, Bellingham, Washington 98227-0010 USA

Telephone +1 3606763290 (Pacific Time) · Fax +1 3606471445

SPIE.org

Copyright (c) 2011, Society of Photo-Optical Instrumentation Engineers.

Copying of material in this book for internal or personal use, or for the internal or personal use of specific clients, beyond the fair use provisions granted by the U.S. Copyright Law is authorized by SPIE subject to payment of copying fees. The Transactional Reporting Service base fee for this volume is $\$ 18.00$ per article (or portion thereof), which should be paid directly to the Copyright Clearance Center (CCC), 222 Rosewood Drive, Danvers, MA 01923. Payment may also be made electronically through CCC Online at copyright.com. Other copying for republication, resale, advertising or promotion, or any form of systematic or multiple reproduction of any material in this book is prohibited except with permission in writing from the publisher. The CCC fee code is 1605 $7422 / 11 / \$ 18.00$.

Printed in the United States of America.

Publication of record for individual papers is online in the SPIE Digital Library.

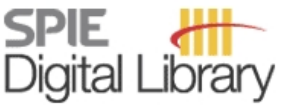

SPIEDigitallibrary.org

Paper Numbering: Proceedings of SPIE follow an e-First publication model, with papers published first online and then in print and on CD-ROM. Papers are published as they are submitted and meet publication criteria. A unique, consistent, permanent citation identifier (CID) number is assigned to each article at the time of the first publication. Utilization of CIDs allows articles to be fully citable as soon they are published online, and connects the same identifier to all online, print, and electronic versions of the publication. SPIE uses a six-digit CID article numbering system in which:

- The first four digits correspond to the SPIE volume number.

- The last two digits indicate publication order within the volume using a Base 36 numbering system employing both numerals and letters. These two-number sets start with $00,01,02,03,04$, $05,06,07,08,09,0 A, 0 B \ldots$. 0Z, followed by 10-1Z, 20-2Z, etc.

The CID number appears on each page of the manuscript. The complete citation is used on the first page, and an abbreviated version on subsequent pages. Numbers in the index correspond to the last two digits of the six-digit CID number. 


\section{Contents}

vii Conference Committee

\section{SESSION 1 THE POWER OF IMAGING}

791002 Imaging enabled plafforms for development of therapeutics (Keynote Paper) [7910-01] J. P. Celli, Wellman Ctr. for Photomedicine, Massachusetts General Hospital, Harvard School of Medicine (United States); I. Rizvi, Wellman Ctr. for Photomedicine, Massachusetts General Hospital, Harvard School of Medicine (United States) and Dartmouth College (United States); A. R. Blanden, Wellman Ctr. for Photomedicine, Massachusetts General Hospital, Harvard School of Medicine (United States) and State Univ. of New York (United States); C. L. Evans, A. O. Abu-Yousif, B. Q. Spring, Wellman Ctr. for Photomedicine, Massachusetts General Hospital, Harvard School of Medicine (United States); A. Muzikansky, Biostatistics Ctr., Massachusetts General Hospital (United States); B. W. Pogue, Dartmouth College (United States); D. M. Finkelstein, Biostatistics Ctr., Massachusetts General Hospital (United States); T. Hasan, Wellman Ctr. for Photomedicine, Massachusetts General Hospital, Harvard School of Medicine (United States)

791004 Magnetomotive molecular probes for targeted contrast enhancement and therapy (Invited Paper) [7910-03]

S. A. Boppart, Univ. of Illinois at Urbana-Champaign (United States)

SESSION 2 IMAGING - PHOTODYNAMIC AND PHOTOTHERMAL THERAPY

791008 Target cell specific antibody-based photosensitizers for photodynamic therapy [7910-07]

L. T. Rosenblum, M. Mitsunaga, J. W. Kakareka, N. Y. Morgan, T. J. Pohida, P. L. Choyke,

H. Kobayashi, National Institutes of Health (United States)

791009 Near-infrared Au nanorods in photodynamic therapy, hyperthermia agents, and near-infrared optical imaging [7910-08]

W.-S. Kuo, C.-N. Chang, Y.-T. Chang, National Cheng Kung Univ. (Taiwan); M.-H. Yang, National Chung Hsing Univ. (Taiwan); Y.-H. Chien, National Cheng Kung Univ. (Taiwan); S.-J. Chen, National Cheng Kung Univ. (Taiwan) and Univ. of Connecticut Health Ctr. (United States); C.-S. Yeh, National Cheng Kung Univ. (Taiwan)

$7910 \mathrm{OB}$ A minimally invasive multifunctional nanoscale system for selective targeting, imaging, and NIR photothermal therapy of malignant tumors [7910-10]

H. N. Green, D. V. Martyshkin, E. L. Rosenthal, S. B. Mirov, The Univ. of Alabama at Birmingham (United States) 
7910 OC Modeling structure and spectra of the kindling fluorescent protein asFP595 [7910-11]

J. R. Collins, I. A. Topol, SAIC-Frederick, Inc. (United States); A. P. Savitsky, A.N. Bach Institute of Biochemistry (Russian Federation) and M.V. Lomonosov Moscow State Univ. (Russian Federation); A. V. Nemukhin, M.V. Lomonosov Moscow State Univ. (Russian Federation) and N.M. Emanuel Institute of Biochemical Physics (Russian Federation)

7910 OD Compact intraoperative imaging device for sentinel lymph node mapping [7910-66]

Y. Liu, A. Q. Bauer, W. Akers, G. Sudlow, K. Liang, D. Shen, M. Berezin, J. P. Culver, S. Achilefu, Washington Univ. in St. Louis (United States)

\section{SESSION 4 NANO PROBES/NANO SHELLS/NANO CAPSULES}

7910 0G Development of ultra-sensitive $\mathrm{Ca}^{2+}$ indicators, yellow cameleon-nanos [7910-14] T. Nagai, K. Horikawa, Hokkaido Univ. (Japan) and Japan Science and Technology Agency (Japan); T. Matsuda, K. Kobayashi, Hokkaido Univ. (Japan)

$7910 \mathrm{Ol} \quad$ Synthesis of gold nanoparticle based beacon for measurement of STAT5b protein expression [7910-16]

J. Xue, L. Shan, Z. Tu, H. Zhu, H. Chen, D. Deng, China Pharmaceutical Univ. (China); Z. Qian, Nanjing Univ. of Aeronautics and Astronautics (China); Y. Gu, China Pharmaceutical Univ. (China)

$79100 \mathrm{~J} \quad$ Optical heating and sensing with plasmonic gold shell and phosphorescent core nanoparticle [7910-17]

L. Sudheendra, I. M. Kennedy, Univ. of California, Davis (United States)

7910 ON Multiphoton luminescence of gold nanorods upon excitation with wavelengths away from their absorption maxima [7910-21]

N. K. Balla, C. J. R. Sheppard, National Univ. of Singapore (Singapore); P. T. C. So, National Univ. of Singapore (Singapore), Massachusetts Institute of Technology (United States), and Singapore MIT Alliance for Research and Technology (Singapore)

\section{SESSION 5 NANO PROBES/NANO SHELLS/NANO CAPSULES II}

$791000 \quad$ Single-cell imaging detection of nanobarcoded nanoparticle biodistributions in tissues for nanomedicine (Invited Paper) [7910-22]

T. Eustaquio, C. L. Cooper, J. F. Leary, Purdue Univ. (United States)

7910 OS In vivo monitoring of organ-selective distribution of $\mathrm{CdHgTe} / \mathrm{SiO}_{2}$ nanoparticles in mouse model [7910-26]

H. Chen, S. Cui, H. Zhu, Z. Tu, L. Shan, J. Xue, D. Deng, J. Zhang, Y. Gu, China Pharmaceutical Univ. (China)

7910 OU Effect of nano-encapsulation on photophysical properties of ICG [7910-27]

S. Gupta, K. Thenkondar, H. Mehta, B. Bahmani, V. Vullev, B. Anvari, Univ. of California, Riverside (United States) 
7910 OW FRET as a tool for the investigation of the fate of Lipidots contrast agents in vivo [7910-29]

J. Gravier, CEA-LETI, MINATEC (France); L. Sancey, J. L. Coll, Institut Albert Bonniot (France);

S. Hirsjärvi, J. P. Benoît, Univ. d'angers (France); F. Vinet, I. Texier, CEA-LETI, MINATEC (France)

\section{SESSION $7 \quad$ NIR-NOVEL PROBES}

$79100 Z \quad$ Near infrared dipyrrin-based fluorogenic chelators for metal ions [7910-32]

S. Thyagarajan, Univ. of Pennsylvania (United States); B. Ghosh, Massachusetts General Hospital (United States); M. A. Filatov, Lomonosov Moscow State Univ. (Russian Federation); A. V. Moore, Massachusetts General Hospital (United States); A. V. Cheprakov, Lomonosov Moscow State Univ. (Russian Federation); S. A. Vinogradov, Univ. of Pennsylvania (United States)

791010 Development of fluorescent tracers for the real-time monitoring of renal function [7910-33]

A. R. Poreddy, B. Asmelash, M. P. Debreczeny, R. M. Fitch, J. N. Freskos, K. P. Galen, K. R. Gaston, J. G. Kostelc, R. Kumar, T. A. Marzan, W. L. Neumann, R. Rajagopalan, T. M. Schoenstein, J.-J. Shieh, J. M. Wilcox, J. K. Wojdyla, R. B. Dorshow, Covidien Pharmaceuticals (United States)

\section{SESSION $8 \quad$ IMAGING WITH NIR PROBES}

791013 Storable near-infrared chemiluminescent probes for in vivo optical imaging [7910-36] B. D. Smith, Univ. of Notre Dame (United States)

791014 Dye-biomolecule conjugates and NIR-fluorescent particles for targeting of disease-related biomarkers [7910-37]

J. Pauli, R. Brehm, M. Grabolle, T. Behnke, Bundesanstalt für Materialforschung und -prüfung (Germany); J. Mathejczyk, Max-Planck-Institut für experimentelle Medizin (Germany); F. Hamann, Univ. Hospital Jena (Germany); F. Alves, Max-Planck-Institut für experimentelle Medizin (Germany); I. Hilger, Univ. Hospital Jena (Germany); U. Resch-Genger, Bundesanstalt für Materialforschung und -prüfung (Germany)

$791015 \quad$ Novel design of multimodal MRI/NIR optical contrast agent [7910-38] K. Guo, F. Lin, W. Akers, J. Zheng, Washington Univ. in St. Louis (United States); B. Teng, O. Vasalatiy, G. L. Griffiths, A. Gandjbakhche, National Institutes of Health (United States); M. Y. Berezin, S. Achilefu, Washington Univ. in St. Louis (United States)

791016 Functional imaging in tumor-associated lymphatics [7910-39]

S. Kwon, E. M. Sevick-Muraca, The Univ. of Texas Health Science Ctr. at Houston (United States)

\section{SESSION 9 FLUORESCENCE AND BIOASSAY}

791019 Fluorescence lifetime imaging to quantify sub-cellular oxygen measurements in live macrophage during bacterial invasion [7910-42]

J. Dragavon, M. Amiri, B. Marteyn, P. Sansonetti, S. Shorte, Institut Pasteur (France) 
79101 A Nanoparticle labeling of mesenchymal stem cells for in vivo imaging and tracking [7910-43]

L. M. Ricles, S. Y. Nam, The Univ. of Texas at Austin (United States); K. Sokolov, The Univ. of Texas M.D. Anderson Cancer Ctr. (United States) and The Univ. of Texas at Austin (United States); S. Emelianov, The Univ. of Texas at Austin (United States) and The Univ. of Texas M.D. Anderson Cancer Ctr. (United States); L. J. Suggs, The Univ. of Texas at Austin (United States)

\section{SESSION 10 NANO GOING NIR}

7910 1C Uptake of PEGylated indocyanine green loaded nanocapsules by cells of reticuloendothelial system [7910-45]

B. Bahmani, S. Gupta, V. Vullev, B. Anvari, Univ. of California, Riverside (United States)

$79101 \mathrm{E}$ Fabrication and optical stability of silanized gold nanorods as multifunctional transducers of near infrared light [7910-47]

F. Ratto, P. Matteini, Istituto di Fisica Applicata Nello Carrara (Italy); S. Centi, Univ. degli Studi di Firenze (Italy); F. Rossi, Istituto di Fisica Applicata Nello Carrara (Italy); F. Fusi, Univ. degli

Studi di Firenze (Italy); R. Pini, Istituto di Fisica Applicata Nello Carrara (Italy)

\section{SESSION 11 NANO PROBES/NANO PLATES/NANO SHELLS/NANO RODS}

$79101 G \quad$ Protein nanospheres: synergistic nanoplatform-based probes for multimodality imaging [7910-50]

M. A. McDonald, National Institute of Standards and Technology (United States);

P. C. Wang, Howard Univ. (United States); E. L. Siegel, Univ. of Maryland (United States)

$79101 \mathrm{H} \quad$ Gold nanorods for applications in biological imaging [7910-51]

Y. Zhang, J. YU, D. J. S. Birch, Y. Chen, Univ. of Strathclyde (United Kingdom)

791011 Design of graphene nanoparticle undergoing axial compression: quantum study [7910-52] O. E. Glukhova, I. V. Kirillova, I. N. Saliy, A. S. Kolesnikova, M. M. Slepchenkov, N.G.

Chernyshevsky Saratov State Univ. (Russian Federation)

\section{SESSION 12 FLUORESCENCE IMAGING AND MICROSCOPY}

$79101 \mathrm{~K}$ Quantitative in vivo lifetime imaging using a time-domain platform with a supercontinuum tunable laser for extended spectral coverage [7910-54]

N. Mincu, D. C. Huang, M. Piche, G. Ma, Advanced Research Technologies Inc. (Canada)

$79101 \mathrm{~N}$ STED super-resolution microscopy in Drosophila tissue and in mammalian cells [7910-57]

L. Lau, Y. L. Lee, M. Matis, J. Axelrod, T. Stearns, W. E. Moerner, Stanford Univ. (United States)

POSTER SESSION

791010 A compression program for chemical, biological, and nanotechnologies [7910-58]

B. S. Tice, Advanced Human Design (United States) 
7910 IP Development and application of fluorescent, green-light activatable caged compound [7910-59]

N. Umeda, The Univ. of Tokyo (Japan) and CREST (Japan); Y. Urano, The Univ. of Tokyo (Japan); T. Nagano, The Univ. of Tokyo (Japan) and CREST (Japan)

Author Index 
Downloaded From: https://www.spiedigitallibrary.org/conference-proceedings-of-spie on 26 Apr 2023

Terms of Use: https://www.spiedigitallibrary.org/terms-of-use 


\title{
Conference Committee
}

\author{
Symposium Chairs \\ James G. Fujimoto, Massachusetts Institute of Technology (United \\ States) \\ R. Rox Anderson, Wellman Center for Photomedicine, Massachusetts \\ General Hospital, Harvard School of Medicine (United States)
}

Program Track Chairs

Paras Prasad, SUNY/Buffalo (United States)

Dan V. Nicolau, The University of Liverpool (United Kingdom)

Conference Chairs

Samuel Achilefu, Washington University in St. Lovis (United States)

Ramesh Raghavachari, U.S. Food and Drug Administration (United States)

Program Committee

Bohumil Bednar, Merck \& Company, Inc. (United States)

Mikhail Berezin, Washington University in St. Louis (United States)

Richard B. Dorshow, Covidien (United States)

Yueqing Gu, China Pharmaceutical University (China)

Hisataka Kobayashi, National Institutes of Health (United States)

D. Michael Olive, LI-COR Biosciences (United States)

Gabor Patonay, Georgia State University (United States)

Attila Tarnok, Universität Leipzig (Germany)

Yasuteru Urano, The University of Tokyo (Japan)

Session Chairs

1 The Power of Imaging

Samuel Achilefu, Washington University in St. Lovis (United States)

2 Imaging - Photodynamic and Photothermal Therapy

Yueqing Gu, China Pharmaceutical University (China)

3 Fluorescent Probes for Imaging

Hisataka Kobayashi, National Institutes of Health (United States) 
$4 \quad$ Nano Probes/Nano Shells/Nano Capsules

Yasuteru Urano, The University of Tokyo (Japan)

$5 \quad$ Nano Probes/Nano Shells/Nano Capsules II

Mikhail Berezin, Washington University in St. Lovis (United States)

6 Fluorescence and FRET

Ramesh Raghavachari, U.S. Food and Drug Administration (United States)

$7 \quad$ NIR-Novel Probes

Richard B. Dorshow, Covidien (United States)

$8 \quad$ Imaging with NIR Probes

D. Michael Olive, LI-COR Biosciences (United States)

9 Fluorescence and Bioassay

Gabor Patonay, Georgia State University (United States)

10 Nano going NIR

Mikhail Berezin, Washington University in St. Louis (United States)

11 Nano Probes/Nano Plates/Nano Shells/Nano Rods

Ramesh Raghavachari, U.S. Food and Drug Administration (United States)

12 Fluorescence Imaging and Microscopy

Attila Tarnok, Universität Leipzig (Germany) 